\title{
BEZPIECZEŃSTWO MALYCH I MIKROPRZEDSIĘBIORCÓW W ŚWIETLE NOWEJ KONSTYTUCJI BIZNESU - ANALIZA I OCENA NAJWAŻNIEJSZYCH PRZEPISÓW
}

\begin{abstract}
Streszczenie: Tekst ma na celu rozważyć nowe rozwiązania prawne stworzone dla bezpieczeństwa małych i mikroprzedsiębiorców. Wprowadzonych ustawą z dnia 6 marca 2018r. wchodzącą w życie 30 kwietnia 2018r. jednocześnie zastępującą ustawę o swobodzie działalności gospodarczej z 2 lipca $2004 \mathrm{r}$. Autor zwraca szczególną uwagę na fakt, iż ustawa prawo przedsiębiorców należy do grupy regulacji tworzących Konstytucję Biznesu, której ideały wymierzone są w dezaktywację najbardziej uciążliwych przepisów utrudniających codzienne funkcjonowanie biznesu. Pierwsze spojrzenia autor opiera na propagowanej ideologii rozpowszechnianej przez grupę ustawodawczą jednocześnie starając się za pomocą dogmatyczno-prawnej analizy skonfrontować z Polską rzeczywistością administracyjną przepisów prawa. Ustawa mimo wszystko zdaniem autora stanowi znaczny krok na przód. Dzięki chociażby takim uproszczeniom dla przedsiębiorców jak m.in.: wprowadzenie odpowiedzialności urzędników administracyjnych za dokonane decyzje, ustanowienie rzecznika małych i średnich przedsiębiorstw, uproszczenie i zmniejszenie obowiązków dla przedsiębiorców.
\end{abstract}

Słowa kluczowe: działalność gospodarcza, konstytucja biznesu, prawo przedsiębiorców, prawo gospodarcze

\section{Analiza najważniejszych przepisów ustawy Prawo Przedsiębiorców - jednego z aktów Konstytucji Biznesu}

Konstytucja biznesu była planem reformy i uproszczenia przepisów, które odwoływały się do prowadzenia działalności gospodarczej. Weszła w życie w dniu 30.04.2018r. Projekt ustawy został opracowany przez Ministra Rozwoju i Finansów, a następnie powierzony Radzie Ministrów do dalszych prac legislacyjnych. Prawo Przedsiębiorców stanowi jeden $\mathrm{z}$ trzonowych członów zmiany struktury i reformy prawno-instytucjonalnej przestrzeni przedsiębiorców oraz wykonywanej przez nich działalności gospodarczej. Koncepcja projektu dotyczy związku między przedsiębiorcami a urzędnikami, załatwiania spraw urzędowych, zakładania działalności gospodarczej jej zawieszania oraz ogólnych zasad tworzenia prawa gospodarczego. Jest zbiorem pięciu ustaw, a za ich sprawą zmieniło się 200 aktów prawnych oraz uchylona została m.in. ustawa o swobodzie działalności gospodarczej i aktualne przepisy dotyczące CEIDG czyli ustawa z lat 80 . Według ustawodawcy całościowo wniesie spójną regulację ogólnych zasad wykonywania działalności gospodarczej w Polsce. Aranżując korzystne, przejrzyste i stabilne warunki do prowadzenia działalności gospodarczej. Umacniając jednocześnie gwarancję praw i wolności przedsiębiorców redukując zagrożenie biznesowe oraz zwiększając

\footnotetext{
${ }^{1}$ Uczelnia Łazarskiego w Warszawie, Katedra Prawa Rzymskiego, Logiki oraz Teorii i Historii Prawa, mats.slaby@gmail.com
} 
zainteresowanie podejmowaniem i wykonywaniem działalności gospodarczej. Jedną z tych kwestii dotyczącą zasad prowadzenia działalności gospodarczej opisuje ustawa Prawo Przedsiębiorców. Zastępująca obowiązującą przez ponad 12 lat Ustawę o Swobodzie Działalności Gospodarczej, która stanowiła generalia publicznego prawa gospodarczego. Dbając o regulacje podejmowania, wykonywania i zakończania działalności gospodarczej na terytorium Rzeczpospolitej Polski. Jednocześnie określając przy tym prawa i obowiązki przedsiębiorców, jak i czynności oraz zadania organów władzy publicznej. Nowa reforma opierając się na zadaniach poprzedniczki wprowadza wiele korzyści zarówno dla młodych początkujących przedsiębiorców jak i tych, bardziej doświadczonych. Zaistniałe zmiany w stosunkach pomiędzy przedsiębiorcami a urzędnikami mają być lepiej dostosowane do aktualnych oczekiwań przedsiębiorców oraz do standardów jakie powinno spełniać rozwojowe państwo pragnące szczycić się dynamiczną gospodarką. Na uwagę zasługuje art.8 Prawa przedsiębiorców wprowadzający zasadę „Co nie jest prawem zabronione, jest dozwolone". Kolokwialnie brzmiący przepis otwiera wiele filarów przedsiębiorczości do dzisiaj nieodkrywanych z racji obaw interpretacji ustawodawcy. Brak tej zasady spowodował dotychczas niemało problemów.

Wiele osób zwraca szczególną uwagę na fakt wprowadzenia w życie nowej regulacji. Mianowicie 90-krotne nowelizowanie starej ustawy o Swobodzie Działalności Gospodarczej. Generujące znaczne braki spójności w wielu dziedzinach. Argumentacja projektu Prawo Przedsiębiorców zaznacza również brak przystawalności z odrębnymi aktami prawnymi uregulowanymi dotychczas przez SwobDziałGospU oraz na brak określenia w niej instytucji prawnych znanych przez przedsiębiorców, przydatnych i potrzebnych tj.: ustawowa gwarancja ogólnych norm konstytucyjnych, w tym zasad zaufania do państwa i unormowanego przez nie prawa lub reguły pewności prawa. W opinii ustawodawcy SwobDziałGospU zawierała szereg zbędnych „przeregulowań” w zakresie rozwiązań i formy wykonawczej dotyczącej m.in. Centralnej Ewidencji i Informacji o Działalności Gospodarczej czy też instytucji pojedynczego punktu kontaktowego dla przedsiębiorców [1]. Według założeń ustawodawcy, PrPrzeds ma - w porównaniu do SwobDziałGospU - w sposób klarowny, spójny i skoncentrowany ułożyć w kraju ogólne reguły funkcjonowania, rozpoczynania oraz zakończenia działalności gospodarczej.

Dodatkowo nowy akt normatywny ma standaryzować w głównej mierze trudności związane z wzmocnieniem gwarancji wolności gospodarczej oraz ofiarować rzetelną i miarodajną notyfikację o ich wprowadzających prawach i obowiązkach $\mathrm{w}$ stosunkach $\mathrm{z}$ organami władzy publicznej i innymi podmiotami np.: innymi przedsiębiorcami czy konsumentami. Pozostałe regulacje zostaną natomiast uregulowane w ustawach odrębnych tworzących rzeczoną „Konstytucję biznesu” [1]. Ustawy odrębne, o których mowa, to m.in. ustawa z 6.3.2018 r. o Rzeczniku Małych i 
Srednich Przedsiębiorców [2], ustawa z 6.3 .2018 r. o Centralnej Ewidencji i Informacji o Działalności Gospodarczej i Punkcie Informacji dla Przedsiębiorcy [3], ustawa z 6.3.2018 r. o zasadach uczestnictwa przedsiębiorców zagranicznych i innych osób zagranicznych w obrocie gospodarczym na terytorium Rzeczypospolitej Polskiej [4] oraz ustawa z 6.3.2018 r. - Przepisy wprowadzające ustawę - Prawo przedsiębiorców (PrPrzeds) [5]. Z uwagi na powyższe, a także mając na względzie, że PrPrzeds wprowadza wiele nowych prawnych jednostek budujących pewność przedsiębiorców, ustawodawca zdecydował, że kolejna nowelizacja Ustawy o swobodzie działalności gospodarczej (SwobDziałGospU) byłaby „kontrproduktywna” [1].

\section{Rzecznik Przedsiębiorców}

Dnia 21 listopada 2017 do sejmu wpłynął projekt ustawy o Rzeczniku Małych i Średnich przedsiębiorstw. Popierało ustawę 253 posłów, przeciw było 147, a 11 wstrzymało się od oddania głosu. Po kolejnej próbie powołania Rzecznika praw osób prowadzących działalność gospodarczą w dniu 30 kwietnia weszła Konstytucja Biznesu. Składająca się z 5 ustaw: jedna dotyczy między innymi ustanowienia rzecznika małych i średnich przedsiębiorstw. Powołanie jego nastąpi w przeciągu pół roku od wejścia w życie ustawy. Mianowany „strażnik” przedsiębiorców do swoich obowiązków zaliczał będzie ustosunkowywanie się do petycji od przedsiębiorców, opiniowanie projektów ustaw jak i odbieranie wyjaśnień od organów i urzędów. Zobowiązany będzie cechować się minimalnie pięcioletnim doświadczeniem w prowadzeniu działalności gospodarczej lub angażem w tworzeniu i stosowaniu prawa gospodarczego. Dodatkowo osoba ta musi być bezpartyjna, a jej kadencja trwać będzie 6 lat. W art. 2 Ustawy o Rzeczniku Małych i Średnich Przedsiębiorstw wykazane są wymogi wobec kandydata. Ma być to obywatel polski z możliwością pełnego korzystania z praw publicznych, wyróżniający się wiedza na temat regulacji prawnych i przedsiębiorczości z zdobytym wyższym wykształceniem. Rzecznik z racji swoich obowiązków powinien poszukiwać sytuacji zaniechania lub działania organu administracji publicznej powodującego zakłócenie interesów lub praw przedsiębiorcy. Reagując na otrzymany wniosek, rzecznik ma możliwość zobrazować inicjatorowi należące mu się prawa i środki działania lub skierować go do innego organu. Zwracając się do instytucji, obliguje do złożenia wyjaśnień i odpowiedzi na temat działań i decyzji w nienaruszalnym terminie trzydziestu dni. Organy będą też zobowiązane do udostępnienia akt i dokumentów spraw zakończonych, z wyjątkiem informacji niejawnych. Rzecznik nie będzie musiał odpowiadać na każdy wniosek, posiada możliwość udzielania odmowy podjęcia działan. Zobowiązany jest wtedy do poinformowania wnioskodawcy, a w razie konieczności może wystąpić o zastępcę do Ministra właściwego do spraw gospodarki. Katalog jego zadań nie jest zamknięty. 
Uprawniony jest między innymi do składania wniosków do Sądu Najwyższego - na zasadach tożsamych do Rzecznika Praw Obywatelskich, Prezesa Sądu Najwyższego czy Prokuratora Generalnego. W celu wyeksplikowania zagadnień prawnych danej sprawy związanych $\mathrm{z}$ powodu rozbieżności występujących $\mathrm{w}$ orzecznictwie. Uprawnienia mają ofiarować możliwości klarowania i zapewniania jednolitości przepisów. W sferze postępowania administracyjnego rzecznik jest pełnomocny do wszczynania postępowań, uczestniczenia $\mathrm{w}$ nich oraz zwracania się do organów i składania skarg do sądu. Artykuł 14 Ustawy o Rzeczniku Małych i Średnich Przedsiębiorstw informuje nas o tym, iż Rzecznik będzie zobowiązany do składania corocznego sprawozdania Prezesowi Rady Ministrów, w ciągu 90 dni od zakończenia roku kalendarzowego, a także do podania do wiadomości publicznej sprawozdania ze swojej działalności w poprzednim roku. Swoje zadania będzie wykonywać za pomoc stworzonego biura rzecznika, będącego państwową jednostką budżetową. Mianowany rzecznik będzie miał zupełne ograniczenie piastowania innego stanowiska, z wyłączeniem funkcji naukowo-dydaktycznych lub naukowych w szkołach wyższych czy instytucie badawczym. Niedozwolone jest, aby rzecznik należał do partii politycznej, czy też wykonywał czynności mogące znacznie wpłynąć na jego obowiązki. Musi dbać o swoją bez stronniczość i bezinteresowność, nie dopuszczając ich zachwiania. Ustawą o finansach publicznych ustawodawca określił górną granicę nakładów finansowych realizowanych z tytułu funkcjonowania biura oraz samego Rzecznika Praw Małych i Średnich Przedsiębiorców. Całkowity budżet może wynieść 170500000 zł. Monitorującym wydatki organem będzie minister właściwy do spraw gospodarki. Stanowisko rzecznika powinno być bardzo pozytywną zmianą dla przedsiębiorców, jego ustanowienie tworzy wpływowego sprzymierzeńca przedsiębiorstw. Mogącego znacznie wpłynąć na łatwiejsze zarządzanie firmą oraz pewność prawa.

Uważam jednak w zgodzie z Konfederacją Lewiatan, iż formowanie nowych kolejnych instytucji publicznych nie tworzy idealnej metody do batalii z „omyłkami” urzędników. Udowadniających nieraz swoje możliwości destrukcyjne w skutkach dla przedsiębiorców. Lewiatan słusznie stwierdził, iż koniecznością nie było utworzenie kolejnego urzędu (choć tak przychylnego przedsiębiorcom) lecz zorganizowanie rozwiązań systemowych pozwalających uniknąc kosztownych dla przedsiębiorstw pomyłek, które często popełniają np. urzędy skarbowe czy sądy. Moim zdaniem dużo istotniejszą zmianą byłoby poszerzanie wiedzy i kultury prawnej urzędników piastujących stanowiska $\mathrm{w}$ urzędach, ponieważ bardzo potrzebna jest poprawa korelacji biznesu z administracją, na różnych szczeblach. Na dzień dzisiejszy nie możemy jeszcze jednoznacznie stwierdzić jak nowy rzecznik będzie sobie radził z pomyłkami popełnianymi przez sądy i urzędy. Słuchając stowarzyszeń zrzeszających przedsiębiorców zauważyć można, iż dużo bardziej przydałyby się 
obniżki podatku VAT oraz uproszczenie systemu podatkowego, a rolę rzecznika powinny wykonywać samorządy gospodarcze. Syntezując akt normatywny zaprojektowany $\mathrm{w}$ celu ułatwienia funkcjonowania na rynku małym i średnim przedsiębiorcom. Mimo to można spotkać się $\mathrm{z}$ falą krytyki wskazującą niedorzeczność powołania kolejnej dodatkowej instytucji wydatkującej i uszczuplającej budżet państwa. Realna ocena funkcjonowania Rzecznika Małych i Średnich Przedsiębiorców po odpowiednim upływie kadencji da nam realistyczne odzwierciedlenie wprowadzanych zmian.

Uwagę należy zwrócić również na obowiązki i odpowiedzialność jaka będzie spoczywać na pierwszym rzeczniku, który będzie musiał zorganizować biuro i przygotować status z jednoczesnym zlokalizowaniem swojej siedziby. W ordynacji zostały dookreślone założenia jakie powinien obrać pierwszy rzecznik przy wyborze siedziby zamieszczanej $\mathrm{w}$ statucie. Uzasadnienie przesłanek jest na tyle istotne, iż zostaną one przedłożone ministrowi do zatwierdzenia. Celem spełnienia wymogu dekoncentracji oraz zasady efektywności. Kierując się sugestią społeczeństwa wyrażoną $\mathrm{w}$ postulatach $\mathrm{w}$ toku procesu legislacyjnego, działalność rzecznika nie powinna skupić się jedynie na stolicy. Uważam jednak, iż największą skuteczność rzecznik wykaże właśnie w Warszawie, miejscu lokalizacji większości instytucji i organów. Skuteczność komunikacji z placówkami wpływać będzie znacznie na ocenę działań rzecznika. Ustawodawca założył, iż dokonanie wyboru zostanie poprzedzone analizą. Godne pochwały jest również obranie kierunku kooperacji rzecznika z przedsiębiorcami małych i średnich przedsiębiorstw. Przedkładane przez analityków wyniki ukazywały konieczność wsparcia właśnie tego sektora, a nie całego środowiska biznesowego. Dodatkowo przypatrując się innym krajom z starszym systemem gospodarczym (USA, Australia, Korea Południowa) to właśnie średnie i małe przedsiębiorstwa potrzebują i uzyskują wsparcia instytucjonalnego w indywidualnych sprawach.

\section{Bezpieczeństwo małych i mikroprzedsiębiorców w świetle nowych przepisów}

Bezpieczeństwo przedsiębiorców rozumiane jako pozycja najbardziej efektywnego wykorzystywania zasobów w celu zapobiegania zagrożeniom i zapewnienia stabilnego funkcjonowania przedsiębiorstwa. Co oznacza zrównoważony rozwój, osiągnięty poprzez wykorzystanie wszelkiego rodzaju zasobów i możliwości biznesowych, które gwarantują najbardziej efektywne wykorzystanie stabilnego działania i dynamicznego rozwoju naukowego, technicznego i społecznego oraz zapobiegania wewnętrznym i zewnętrznym negatywnym wpływom. Analizując pewność przedsiębiorstw, spotykamy się z częstym podziałem na bezpieczeństwo zewnętrzne i wewnętrzne. Zewnętrzne ukierunkowane $\mathrm{w}$ identyfikację i eliminację zagrożeń biznesowych związanych 
z działalnością przedsiębiorstwa z innymi podmiotami (osobami, organizacjami) oraz organami wykonawczymi, a także szeroko dorozumianą ochronę. Bezpieczeństwo wewnętrzne powinno mieć na celu identyfikację i eliminację zagrożeń związanych z wewnętrznymi procesami biznesowymi i personelem przedsiębiorstwa. Istotne znaczenie mają również uwarunkowania ekonomiczne. Jakość bazy legislacyjnej, jakość podatkowa czy możliwości współpracy z wszelkimi rynkami. Należy wspomnieć również o samym potencjale regionu, który ma istotne znaczenie dając możliwość zapewnienia przewidywalności zewnętrznych zagrożeń istotnych dla przedsiębiorców. Istotnie odczuwalnym negatywnym źródłem może być świadome lub nieświadome działanie poszczególnych urzędników lub organów państwowych. Głównym celem bezpieczeństwa przedsiębiorstw jest zapewnienie jego stabilnej i wydajnej pracy oraz wysokiego potencjału przyszłego rozwoju. Poprzez osiągnięcie stabilnej i wysokiej wydajności finansowej idącej w parze z niezależnością. Stawiając dodatkowo przy tym na profesjonalizm w zarządzaniu jak i wysoką kwalifikację personelu. Spokój gwarantuje możliwość dokonania selekcji i analizy występujących niebezpieczeństw dla każdego filaru przedsiębiorczości, dzięki możliwości stworzenia środków antymonopolowych. Dlatego zauważyć należy, iż bezpieczeństwo przedsiębiorczości jest różnokierunkowe, szeroki i istotny zakres ma natomiast gwarancja bezpiecznych stosunków społeczno-gospodarczych - w pełnym zakresie od państwa do obywateli. Dlatego zamiar ustawy należy intepretować jako stworzenie fundamentu zapewniającego stabilność przy jednoczesnym wzroście dobrobytu małych przedsiębiorców. Mimo wszystko każde przedsiębiorstwo jest całkowicie indywidualne, a komfort egzystencji biznesowej jest w dużej mierze uwarunkowany funkcjonującymi prawnymi zasadami i zwyczajami państwa.

Konstytucja Biznesu to wszechstronna modernizacja przepisów prawa gospodarczego, a polepszenie środowiska prawno-instytucjonalnego dla przedsiębiorców jest jej celem. Zestaw aktów normatywnych klarownie i zwięźle opisujący ustrój gospodarczy Polski w duchu wolności gospodarczej. Nazywana „biznesowym zbiorem praw podstawowych” obejmującym zasady i gwarancje przysługujące przedsiębiorstwom. Pakiet obejmujący nową ustawą praktykę udziału przedsiębiorstw zagranicznych i innych osób zagranicznych w obrocie gospodarczym w Polsce. Dotychczas przepisy na ten temat zawarte były w trzech różnych ustawach w niespójny sposób. Aktualnie napływowi przedsiębiorcy mają przejrzysty i spójny akt prawny. Dlatego zbiór ustaw dotyczących przedsiębiorczości jest najbardziej kompleksową reformą prawa gospodarczego od prawie 30 lat. Nadmienię moją ogromną nadzieje idące w kierunku powstałych pięciu ustaw. Wszakże odczuwalność kolosalnej zmiany może być dość utrudniona to jest to znacznie bardziej sprzyjający pogląd ustawodawcy $\mathrm{w}$ stosunku do przedsiębiorców. Budujący lepszą polską rzeczywistość biznesową. Konstytucja Biznesu powinna przede wszystkim pomóc 
stworzyć na nowo partnerskie relacje między przedsiębiorcami a urzędnikami. Ułatwiając założenie oraz prowadzenie w szczególności małych firm w kraju, co dotychczas było uciążliwe. Spośród wielu zmian warto wyszczególnić jedną z nich, wprowadzającą odpowiedzialność urzędnika z tytułu wykonywanej pracy - art.13 Prawo Przedsiębiorców. Pierwszorzędnie przepis brzmi idealnie. Jednak nie możemy wykluczyć faktu, iż narzucenie odpowiedzialności za podejmowane decyzje może obrać również odwrotny kierunek i w pełni zblokować administrację. Ustawodawca nie bierze pod uwagę strachu przed odpowiedzialnością i możliwością pociągnięcia do odpowiedzialności urzędnika, mogącego zblokować i zmuszać do odsyłania każdej problematycznej sprawa w celu doradztwa i podjęcia decyzji przez przełożonych. Moje obawy wywołane, są złym doświadczeniem podejścia urzędników. Mimo to przepisy dają nadzieję, iż urzędnik zrozumie, jaki ma obowiązek z racji wykonywanej pracy. Na tej podstawie można twierdzić, iż bezpieczeństwo i komfort załatwiania spraw jest w zasięgu ręki. Jednak z znaczną zależnością interpretowania przepisów i funkcjonowania przez samych urzędników. Dlatego mimo znacznej świadomości wśród polskich przedsiębiorców, rodzi się wiele pytań i obiekcji w stosunku do nowych aktów prawych. Nadmienione zmiany obligują do wdrożenia szeregu nie tylko prawnych, technicznych, ale i logistycznych modernizacji.

\section{Bibliografia}

[1] Uzasadnienie do rządowego projektu ustawy - Prawo przedsiębiorców z 21.11.2017 r., druk nr 2051 Sejmu VIII kadencji, dostępny na: http://www.sejm.gov.pl/sejm8.nsf/ druk.xsp?nr=2051 (sprawdzono: 16.4 .2018 r.), s. 2

[2] Ustawa z dnia 6 marca 2018 r. o Rzeczniku Małych i Średnich Przedsiębiorców (Dz.U. 2018 poz. 648)

[3] Ustawa z 6.3.2018 r. o Centralnej Ewidencji i Informacji o Działalności Gospodarczej i Punkcie Informacji dla Przedsiębiorcy (Dz.U. z 2018 r. poz. 647).

[4] Ustawa z 6.3.2018 r. o zasadach uczestnictwa przedsiębiorców zagranicznych i innych osób zagranicznych w obrocie gospodarczym na terytorium Rzeczypospolitej Polskiej (Dz.U. z 2018 r. poz. 649)

[5] Ustawa z 6.3.2018 r. - Przepisy wprowadzające ustawę - Prawo przedsiębiorców (Dz.U. z 2018 r., poz. 650)

[6] Ustawa z dnia 6 marca 2018 r. - Prawo przedsiębiorców (Dz.U. z 2018 r. poz. 646)

[7] Kotowicz B., Słaby M. Ułatwienia dla przedsiębiorców - próba oceny nowych rozwiazań prawnych. Monitor Prawniczy Dodatek, Nr 13/2018

[8] Ustawa z dnia 2 lipca 2004 r. o swobodzie działalności gospodarczej (Dz.U. z 2004 r. $\mathrm{Nr} 173$ poz. 1807 ze zm.)

[9] Sienkiewicz K., Rzecznik Małych $i$ Średnich Przedsiębiorców, 2018; https://konstytucjabiznesu.biz/rzecznik-malych-srednich-przedsiebiorcow/ 20.02.2018 
[10]Miazek K., Rzecznika Małych i Średnich Przedsiębiorców poznamy za pół roku. 2018; http://www.wirtualnemedia.pl/artykul/rzecznik-malych-i-srednich-przedsiebior cow\# 30.04.2018

[11]Kostrzycka B. Ustawa Prawo przedsiębiorców a zmiany relacji $z$ organami skarbowymi 2018; https://poradnikprzedsiebiorcy.pl/-ustawa-prawo-przedsiebiorcowa-zmiany-relacji-z-organami-skarbowymi 09.05.2018

[12] https://www.premier.gov.pl/mobile/wydarzenia/decyzje-rzadu/projekt-ustawy-orzeczniku-malych-i-srednich-przedsiebiorcow.html

[13]https://konstytucjabiznesu.biz/rzecznik-malych-srednich-przedsiebiorcow/

\title{
SECURITY OF SMALL AND MEDIUM ENTERPRISES IN THE EYES OF THE LAW BUSSINES CONSTITUTION - TO SUBJECT OF IMPORTANT LEGAL RULES TO ANALYSIS
}

\begin{abstract}
The article is an analysis of new legal solutions created for the safety of small and microentrepreneurs, which were implemented by the Act of March 6, 2018 coming into force on April 30, 2018, and replacing the Freedom of Business Activity Act of July 2, 2004. The author pays particular attention to the fact that the Act belongs to a group of regulations from the Business Constitution, goal of which is deactivation of the most anti-business regulations. The author bases his views on the propagated ideology, disseminated by the legislative group and he is trying the same time to confront Polish administrative reality with new regulations, using dogmatic and legal analysis. Notwithstanding, in the author's opinion, the Act is a significant step forward, due to such facilitations for entrepreneurs as, among others: implementation of administrative officials responsibility for their decisions, establishing an advocate of small and medium enterprises, simplifying and reducing obligations for businesses.
\end{abstract}

Key words: economic activity, business constitution, entrepreneurs' law, business law

Data przestania publikacji do Redakcji: 15.08.2018 Data akceptacji publikacji przez Redakcję: 20.09.2018 